\title{
Nano-sized graphitic carbon in authigenic tube pyrites from offshore southwest Taiwan, South China Sea, and its implication for tracing gas hydrate
}

\author{
ZHANG Mei ${ }^{1}$, SUN XiaoMing ${ }^{1,2,3^{*}}, \mathrm{XU} \mathrm{Li}^{2,3}, \mathrm{XU} \mathrm{HuiFang}^{4}, \mathrm{KONISHI} \mathrm{Hirom}^{4}, \mathrm{LU}^{4}$ Yang $^{1}$, \\ LU HongFeng ${ }^{5} \&$ WU ZhongWei ${ }^{1}$ \\ ${ }^{1}$ Department of Earth Sciences, Sun Yat-sen University, Guangzhou 510275, China; \\ ${ }^{2}$ School of Marine Sciences, Sun Yat-sen University, Guangzhou 510275, China; \\ ${ }^{3}$ Guangdong Provincial Key Laboratory of Marine Resources and Coastal Engineering, Guangzhou 510275, China; \\ ${ }^{4}$ Department of Geosciences, University of Wisconsin, Madison WI 53706, USA; \\ ${ }^{5}$ Guangzhou Marine Geological Survey, Ministry of Land and Resources, Guangzhou 510075, China
}

Received December 30, 2010; accepted April 18, 2011

\begin{abstract}
Gas hydrates are a significant energy resource and are usually detected by bottom simulating reflection and submarine geochemical anomalies. Authigenic minerals are related to gas hydrates, with carbonates, sulfates and sulfides being important tracing minerals. Authigenic tubular pyrites were collected from offshore southwest Taiwan in the South China Sea, and were investigated by scanning electron microscopy(SEM) and high-resolution transmission electron microscopy (HRTEM). Authigenic tubular pyrite was composed of framboidal pyrite, within which nanosized graphitic carbon of low crystallinity was discovered. The graphitic carbon coexisted with pyrite and had a texture similar to carbon nanotubes and nanocones, indicating that they likely precipitated from carbon supersaturated C-H-O fluid. Pyrite may act as a catalyst for the conversion of $\mathrm{CH}_{4}$ to $\mathrm{C}$. The discovery of nanosized graphitic carbon in pyrite indicated it was deposited in sediments that were supersaturated with methane fluid. Thus, nanosized graphitic carbon may be another tracing species for submarine gas hydrates. The discovery of nanosized graphitic carbon deposited in a low temperature environment will enlighten our understanding of the laboratory synthesis and industrial production of graphitic carbon.
\end{abstract}

nano-sized graphitic carbon, authigenic tube pyrite, gas hydrate, South China Sea

Citation: Zhang M, Sun X M, Xu L, et al. Nano-sized graphitic carbon in authigenic tube pyrites from offshore southwest Taiwan, South China Sea, and its implication for tracing gas hydrate. Chinese Sci Bull, 2011, 56: 2037-2043, doi: 10.1007/s11434-011-4527-7

Gas hydrates are an ice-like crystalline material consisting predominantly of methane and water molecules, and are formed under high pressure and low temperature on continental slopes/rises [1]. As a newly discovered clean energy source during the last two decades, gas hydrates are gaining worldwide attention on account of their importance in energy exploration, and through increasing awareness of seafloor structure geo-hazards (stability) and global climate change. Gas hydrates predominantly occur at depths of

*Corresponding author (email: eessxm@mail.sysu.edu.cn)
300-3000 $\mathrm{m}$ around the edges of continents and in marginal marine basins. Most information on the distribution, concentration, composition and origin of gas hydrates in deep marine sediments comes from geophysical evidence such as bottom simulating reflection and strong seafloor acoustic reflectivity. These techniques are commonly used to infer the distribution of gas hydrates on continental margins, in addition to gas hydrate samples collected during the deep sea drilling project and ocean drilling program.

Pyrite is a common authigenic mineral within the marine sediments of the continental margin. It is the product of 
sulfate reduction and records information about changes in sediment environment, so is an important research focus for early stage diagenesis. Under normal marine environmental conditions, pyrite arises from the bacterial reduction of sulfate, which enables the biogenic oxidation of organic matter by anaerobic microorganisms (reaction (1)). Within $\mathrm{CH}_{4}$ containing marine sediments, pyrite is the product of the anaerobic oxidation of methane (AOM), performed by numerous methanotrophic archaea and sulfate reducing bacteria (reaction (2)).

$$
\begin{gathered}
2 \mathrm{CH}_{2} \mathrm{O}+\mathrm{SO}_{4}^{2-} \rightarrow \mathrm{H}_{2} \mathrm{~S}+2 \mathrm{HCO}_{3}^{-} \\
\mathrm{CH}_{4}+\mathrm{SO}_{4}^{2-} \rightarrow \mathrm{HCO}_{3}^{-}+\mathrm{HS}^{-}+\mathrm{H}_{2} \mathrm{O}
\end{gathered}
$$

Sassen et al. [2] discovered rods/tubes of framboidal pyrite in sediments from the Gulf of Mexico continental slope, and concluded they were formed by the anaerobic oxidation of sulfate. The released $\mathrm{HS}^{-}$reacted with free $\mathrm{Fe}$, and precipitated pyrite was fossilized by giant filamentous bacterium Beggiatoa within the sediment. Huang et al. [3] reported that pyrite tubes from sediments southwest of Taiwan may also act as micro-vents for methane seepage from marine sediment. Lu et al. [4] demonstrated that authigenic pyrite content in sediments from the Southwest Taiwan Basin had organic carbon content and sulfate/methane concentrations consistent with those from pore water. Until now, direct evidence of the genetic relationship between authigenic pyrite and gas hydrates is still lacking.

In the current study, field emission scanning electron microscopy (FESEM) and high resolution transmission electronic microscopy (HRTEM) were used to observe the shapes and structures of authigenic pyrites from sediments. Pyrite tubes were predominantly composed of framboidal pyrite, within which nano-sized graphitic carbon of low crystallinity was discovered. The implications of graphitic carbon for tracing gas hydrates are discussed.

\section{Geological setting of the study area}

The South China Sea (SCS) is one of the biggest marginal seas in the West Pacific, and is located at the junction of the Eurasian, Pacific and Indian-Australian tectonic plates. Margins of the SCS exhibit a unique and complex tectono-sedimentary framework [5]. Since the Mesozoic era, the SCS has developed several basins and terraces abundant in organic materials following a series of structural movements, and thus formed a favorable place for the deposition of gas hydrates [6-8]. It is generally accepted that the extensive stretching and thinning of the continental crust between China and Borneo took place in late Mesozoic era, as a result of sustained subduction at the western margin of the Pacific plate. The offshore area of southwest Taiwan in the SCS is a complicated sedimentary framework formed under tectonic conditions described as follows: the SCS NW mar- gin is a passive tectonic margin formed from $1-3 \mathrm{~km}$ thick sediment. The eastern margin is an active collisional margin, composed of active margin sediment in a forearc trench on the depressed eastern margin of the SCS plate and in imbricated sediments of the Heng-Ch'un Ridge. The middle region is composed of passive margin sediment that has been encroached upon by the active margin, with a resulting thick sediment build-up ( $>8 \mathrm{~km})$ [9]. The tectonic framework of southern Taiwan is predominantly controlled by the collision of an accretionary wedge on the ocean-side of the volcano arc. The thick sedimentation of the fore-arc trench located in the west of the thrust deformation zone [9] was caused by sedimentation and subduction of the ocean crust. The sediments of the accretionary wedge exhibit secondary deformation. The western anticline is enveloped by the eastern inclined imbricate thrust fault [10]. Previous studies showed that there are three potential regions for gas hydrate reserves southwest of Taiwan, all possessing similar structure and stratum. Gas hydrate formation is most favorable in water depths of $1-3.5 \mathrm{~km}$ within these three prospective areas [9]. Sampling evidence for gas hydrate deposits have now been found in the SCS, with several prospects having been initiated [7,11-13]. Gas hydrate specimens have been sampled $200 \mathrm{~m}$ under the sediment surface in the Shenhu Area [14].

\section{Materials and methods}

Pyrites were collected from the GC10 site $\left(21.3^{\circ} \mathrm{N}\right.$, $119.19^{\circ} \mathrm{E}$, Figure 1), which was drilled by gravity piston during SO-177, operated by Ocean IV from the Guangzhou Marine Geological Survey and SONNE from Germany in 2004. The sampling site was $3008 \mathrm{~m}$ in depth and had a 973 $\mathrm{cm}$ bore. It is located in the northeast SCS, near the bottom of the continental slope of Taiwan Island. During SO-177, methane-fueled microbial communities and bivalves were discovered by SONNE for the first time. Carbonate chimneys formed by methane vent were also observed [15]. A bottom simulating reflection has also been detected and revealed the occurrence of gas hydrates [16]. Samples were preserved at $4^{\circ} \mathrm{C}$ following return from the sampling site. After drying, $7.00 \mathrm{~g}$ was sampled each time staring at the top of the core and working down at intervals of $20 \mathrm{~cm}$. Samples were sieved with distilled water using a $0.063 \mathrm{~mm}$ sifter, and pyrite and microfaunas remained after the washing out of clay minerals. Pyrites were tubular, spherical and some were filled with microfaunas. Tubular pyrites were the most commonly observed, in both hollow and solid form of $0.10-6.00 \mathrm{~mm}$ in length and $0.25-0.30 \mathrm{~mm}$ in outer diameter. Their spherical structure was obvious from their cross sections, and their inner layer consisted of framboidal pyrite. Pentagonal dodecahedron-like pyrite particles were packed closely in the center, and were surrounded by pyrite particles and other debris [17]. 


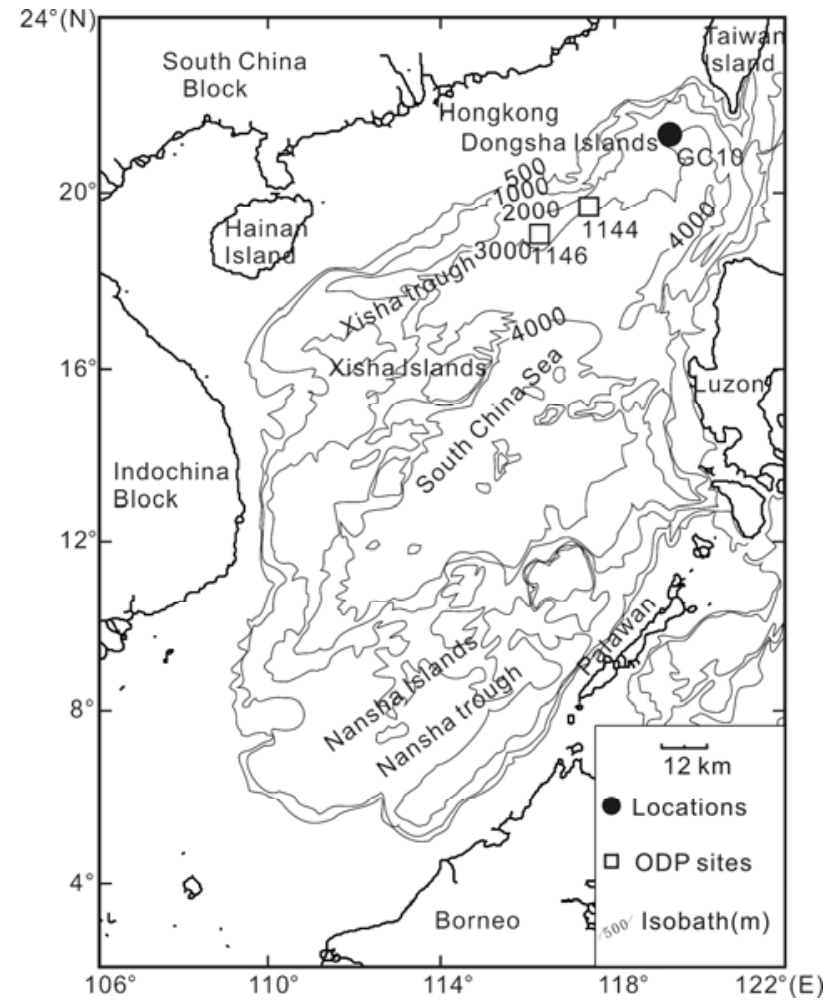

Figure 1 Sampling location of GC10 core (black dot) in bathymetry of the South China Sea (modified from Guo et al. [18]).

Tube pyrites in sediments were handpicked with the aid of a stereomicroscope, and their shapes and structures were observed using SEM and TEM. SEM samples were prepared from original tube pyrite, and polished thin sections on sample stages were then carbon-coated. SEM imaging was performed at the Material Sciences Center, University of Wisconsin, USA, using a Zeiss 1500XB Cross Beam Workstation equipped Quanta 400 SEM with a Genesis energy-dispersive X-ray spectroscopy (EDS) probe made by EDAX. TEM samples were prepared by dispersing powders of tube pyrite on a sample vessel. TEM and selected-area electron diffraction (SAED) measurements were obtained using a Philips CM 200UT microscope (spherical aberration coefficient (Cs) of $0.5 \mathrm{~mm}$, and point-to-point resolution of $0.19 \mathrm{~nm}$ ) equipped with an EDS analyzer (NORAN Voyager), operated at an accelerating voltage of $200 \mathrm{kV}$.

\section{Results}

\subsection{SEM}

SEM images showed the Southwest Taiwan Basin pyrite was mainly composed of framboidal pyrite (Figure 2a, b, d). In the tube pyrites inner wall, framboidal pyrites were packed with octahedral microcrystals (Figure 2d). Within the middle layer, spherical pyrite aggregates consisted of a framboidal core with pyrite spherules. The core was com- posed of pyrite microcrystals, and the entire pyrite octahedron was aggregated to the wall of the tube (Figure 2b). There were other minerals present including quartz, silicate and sulfate. EDS indicated that $\mathrm{C}$ was also present (Figure $2 \mathrm{f}$ ). Filamentous material was present on the pyrite surface (Figure 2c), and was composed of C (Figure 2e) which may have resulted from bacteria.

\subsection{HRTEM}

Framboidal pyrite was observed using HRTEM and nanosized graphitic carbon (Figure 3) was discovered. Faint diffraction mottles in the SAED pattern of graphitic carbon (Figure 3e) indicated that crystallinity was low. There were also some bright diffraction mottles belonging to the host pyrite. The EDS spectrum (Figure 3d) showed strong peaks characteristic of $\mathrm{Cu}, \mathrm{S}, \mathrm{Fe}$ and $\mathrm{C}$. The $\mathrm{Cu}$ peak arose from sample holder, and $\mathrm{S}$ and Fe from pyrite. Their coexistence indicated the close intergrowth relationship between graphitic carbon and pyrite.

Figure 4 shows HRTEM images of various nanosized graphitic carbon shapes from the samples. Two types of graphitic carbon were apparent, including nanotubes and nanocones (Figure 4f). The former were characterized by polygonal flakes (Figure 4a, b, c, e) with long-range ordered aromatic layers and graphitic plates (Figure 4d,e). The diameter of the polygonal flakes was generally 10-20 nm, and they were composed of several graphite layers. The layers were composed of 2-10 layers and the maximum plate diameter was $20 \mathrm{~nm}$. The tubular graphite cone was composed of four cylindrical graphite sheets, with hollow interiors and a maximum length and width of 58.19 and $8.71 \mathrm{~nm}$, respectively. They had similar microstructures with the cylinder structure being intermediate of graphite cones and graphitic carbon nanotubes. Layer length increased upon proceeding from inner to outer layers of the nano graphite cone. Microand nanoscale graphite cones and tubes have been observed in graphite ores in a previous study [19].

\section{Discussion}

Within the continental shelf environment, large amount of terrigenous materials are transported to the ocean, and subsequently deposited along the continental margin. Much organic material is also deposited, such as that found in the Southwest Taiwan Basin in the SCS. In the anoxic environment, anoxic sulfate reduction and permanent burial are the two primary pathways that determine the fate of sedimentary organic carbon in shelf sediments [20]. Within anoxic sediment, organic carbon is usually degraded to $\mathrm{CH}_{4}$, $\mathrm{CO}_{2}$ and $\mathrm{H}_{2}$ by methanogenic bacteria. As the end product of carbon degradation, graphitic carbon is extensively observed in reduced sediment environments. The transformation of carbonaceous matter through prograde metamor- 

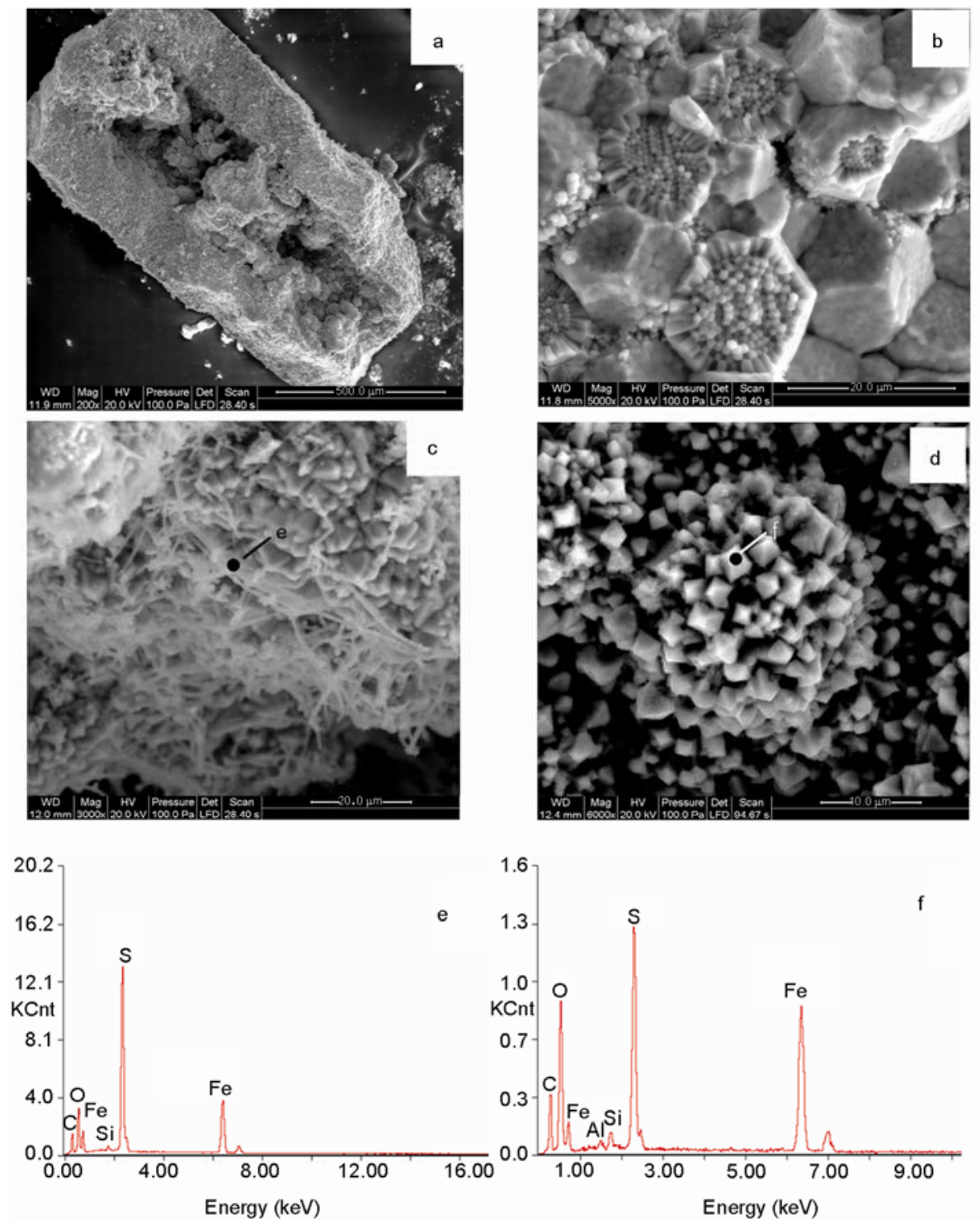

Figure 2 SEM images and EDS spectra of tube framboidal pyrite from the Southwest Taiwan Basin. a, b and d, framboidal pyrite; c, filaments on framboidal pyrite surface; e, EDS spectrum and chemical composition of filaments at point e in c; f, EDS spectrum microcrystals at point $\mathrm{f}$ in d. Sample number was GC10-19b.

phism (graphitization) and deposition from $\mathrm{C}-\mathrm{O}-\mathrm{H}$ fluids are the two major processes responsible for the formation of graphite in rocks [21]. The former arises from the in situ metamorphism of organic matter within host sediments, and typically occurs as dispersed graphite flakes. Such graphite is usually referred to as syngenetic graphite. In contrast, fluid-deposited graphite is precipitated from $\mathrm{C}-\mathrm{O}-\mathrm{H}$ fluids that have become saturated with respect to graphite, and typically occurs in veins. This formation is referred to as epigenetic, because the graphite is formed later than the rocks that host it. In the current study, graphite occurred within the authigenic pyrite tube, and the mineralogical study indicated there were no graphite grains within the surrounding deep sea mud. Thus, the graphitic carbon was most likely deposited from C-H-O saturated fluid.
Luque et al. [21-23] and Pasteris and Chou [24] systematically studied the mineralogy and crystallinity of various fluid-deposited graphite. Their studies demonstrated that temperature was an important factor in the formation of epigenetic graphite deposits. The formation temperature for fluid deposited highly crystalline graphite is higher than that for metamorphic graphite, since its nucleation and high crystallinity growth in a carbon-bearing fluid required more activation energy. This could be one of the reasons why highly crystalline fluid deposited graphite is generally restricted to high temperature environments [24]. The precipitation of graphite from low-temperature fluids requires two conditions: the initial concentration of carbon in $\mathrm{C}-\mathrm{H}-\mathrm{O}$ fluids needs to be very high (supersaturated) because carbon solubility in low temperature C-O-H fluids is very high [25]; 

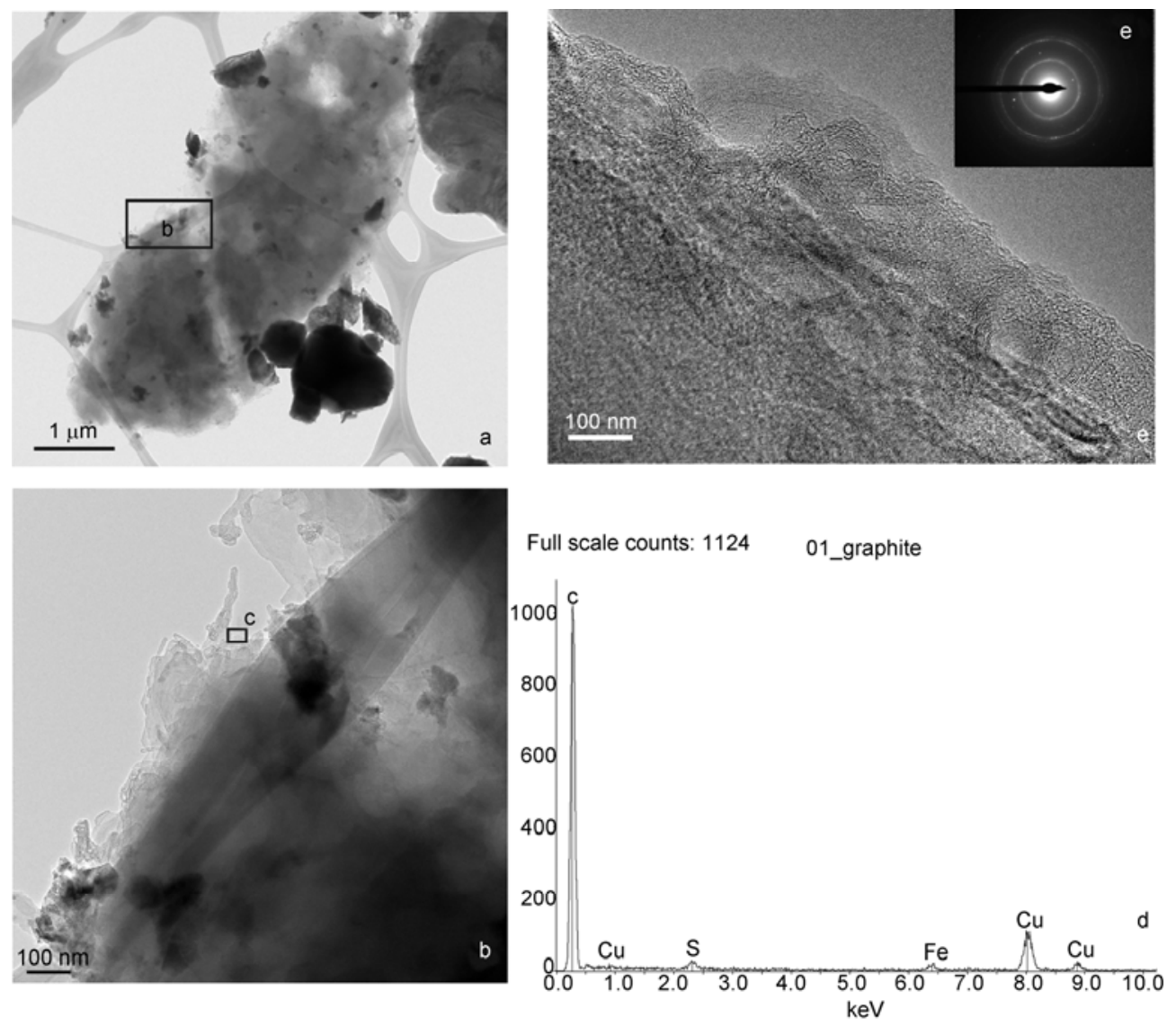

Figure 3 HRTEM image and SAED pattern of nano-sized graphitic carbon from sample GC10-16b: a, TEM image; $b$ and c, HRTEM images where b and $\mathrm{c}$ are magnifications of rectangles $\mathrm{b}$ and $\mathrm{c}$ respectively; d, EDS spectrum; e, SAED pattern of graphitic carbon.

deposited graphite crystallinity will be very low (even amorphous) because lower crystallinity material is easier to nucleate [21].

Gas hydrates are stable at low-temperature (usually less than $10^{\circ} \mathrm{C}$ ) [26]. The precipitation of low crystallinity graphite at this temperature indicated the $\mathrm{C}$ concentration of the fluid was very high. Graphite precipitation is described by chemical reaction (3):

$$
\mathrm{CH}_{4}+\mathrm{O}_{2} \rightarrow \mathrm{C}+2 \mathrm{H}_{2} \mathrm{O}
$$

In the upper area of the gas hydrate-bearing sediment, gas hydrates will decompose into water and methane when temperate increases and/or pressure decreases:

$$
\left(\mathrm{CH}_{4}\right)\left(\mathrm{H}_{2} \mathrm{O}\right)_{6} \rightarrow \mathrm{CH}_{4}+6 \mathrm{H}_{2} \mathrm{O}
$$

Low crystallinity graphite and nanotube-like carbon are closely associated with pyrite framboids, indicating that they may be syngenetic. Nano-sized elemental C suggested that gaseous methane was probably present in fluid. When upwelling methane-bearing fluid met the pyrite microcrystals, methane and oxidants $\left(\mathrm{Fe}^{3+}, \mathrm{Mn}^{4+}\right.$ and $\left.\mathrm{O}_{2}\right)$ exchanged electrons on the pyrite surface. This incomplete oxidation resulted in the transformation of methane to nanosized elemental C. Pyrite is a semiconductor and may have served as a catalyst during reaction (3). Currently, the most effective method for preparing carbon nanotubes is thermal chemical vapor deposition. Carbon matter is vaporized and then deposited as carbon nanotubes using various metal catalysts including $\mathrm{Fe}$, $\mathrm{Co}$ and $\mathrm{Ni}$ [27]. This synthesis can also be performed in solution in the presence of solid catalysts $[28,29]$.

The location of the GC10 core is believed to be a potential area for gas hydrate deposits, and authigenic minerals such as pyrite and carbonate (aragonite, high-Mg calcite and dolomite) have been reported in previous studies. Geochemical and geophysical evidence also suggests that gas hydrates are likely to occur in this region [3,4]. The discovery of nanosized graphitic carbon within authigenic pyrite tubes suggested that $\mathrm{CH}_{4}$ supersaturated $\mathrm{C}-\mathrm{H}-\mathrm{O}$ fluid is probably present in the marine sediments, and may be a mineral indicator for gas hydrates. The discovery of low temperature deposited graphite has implications for the industrial room temperature synthesis of graphite.

\section{Conclusions}

Nano-sized graphitic carbon was found in authigenic tubu- 

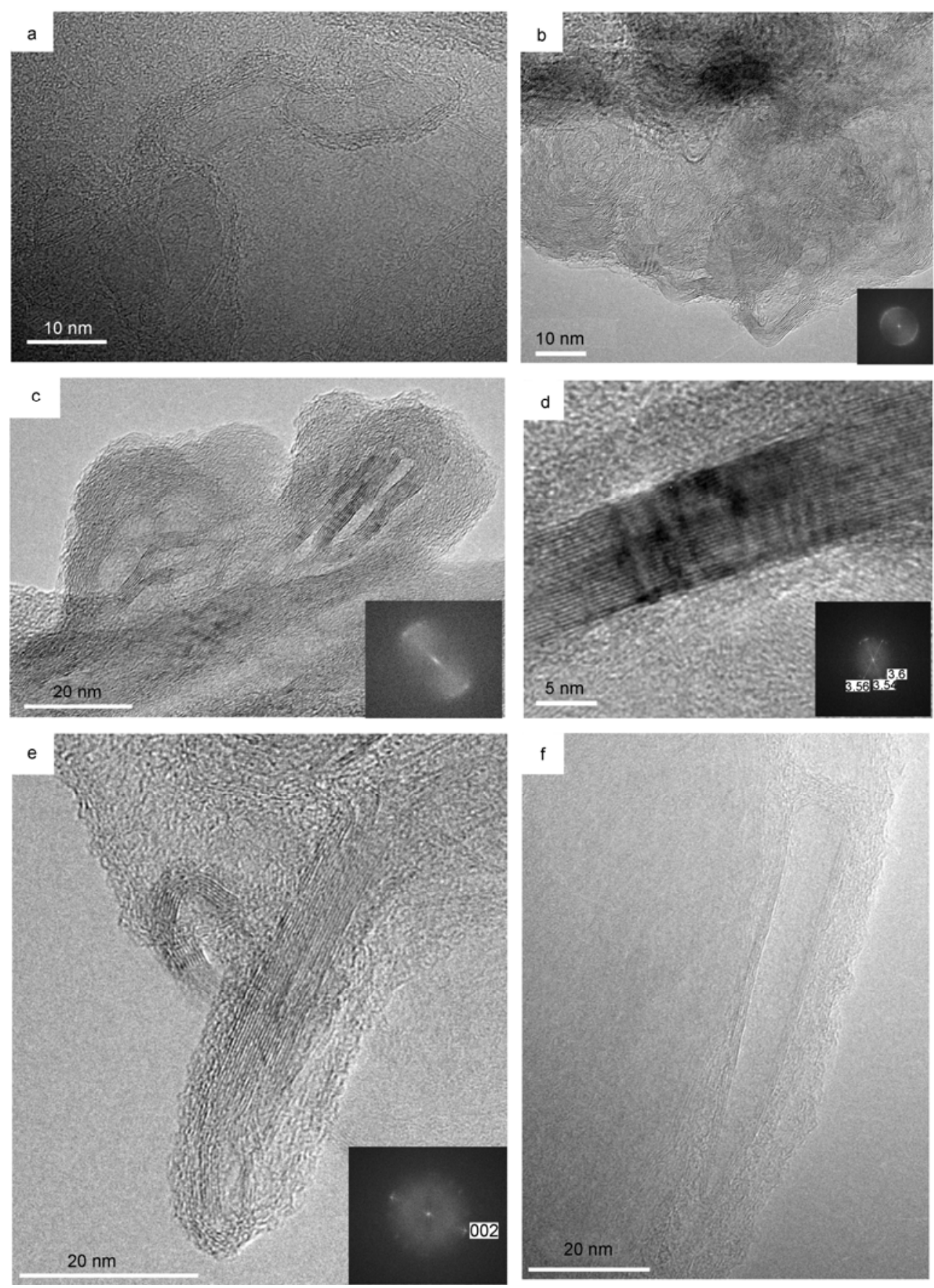

Figure 4 High-resolution TEM images of nanosized graphitic carbon structures in pyrite. a, Ring-shape; b, graphitic carbon; c, growth defect; d, carbon plate; e, nanotube; f, graphitic cone. The sample number of a, d, e and f was GC10-16b, and that of b and c was GC10-19b.

lar pyrite from the GC10 site; a prospective area offshore southwest Taiwan, South China Sea. The carbon showed a low degree of crystallization, which indicated it crystallized from reduced methane supersaturated C-H-O fluid. Framboidal pyrite may act as a catalyst in the precipitation of carbon. Authigenic pyrite containing carbon inclusions may be used as a tracing mineral for gas hydrates in marine sediments.
Engineers in the cold storage din the Guangzhou Marine Geological Survey are thanked for their support in sediment sampling. We appreciate the assistance of Zhou Ning, Tian Chiying, Dr. Huang Shengxiong and Huang Yongyang. This work was supported by the Project of the 10th and 11th Five-Year Research and Development of International Seabed (DYXM115-02-1-11), the Specialized Research Fund for the Doctoral Program of Higher Education (20090171120019), the Fundamental Research Funds for the Central Universities (09lgpy09) and the Project of Key Laboratory of Marginal Sea Geology, Guangzhou Institute of Geochemistry and South China Sea Institute of Oceanology, CAS (MSGL08-01 and MSGLCAS03-4). 
1 Kvenvolden K A. Gas hydrates-geological perspective and global change. Rev Geophys, 1993, 31: 173-187

2 Sassen R, Roberts H H, Carney R, et al. Free hydrocarbon gas, gas hydrate, and authigenic minerals in chemosynthetic communities of the northern Gulf of Mexico continental slope:relation to microbial processes. Chem Geol, 2004, 205: 195-17

3 Huang Q Y, Jian Z W. The comparison of geological background between gas hydrate in accretionary prism of southwest of Taiwan and carbonate concretion from methane in the western foothill of Taiwan Orogen (in Chinese). Prosemin Geol Sci World Chin, 2005, 57

4 Lu H F, Chen F, Liao Z L, et al. Authigenic pyrite rods from the core HD196A in the Northeastern South China Sea (in Chinese). Acta Geol Sin, 2007, 81: 519-525

5 Wang H B, Zhang G X, Yang M Z, et al. Structural circumstance of gas hydrate deposition in the continent margin, the South China Sea (in Chinese). Mar Geol Quat Geol, 2003, 23: 81-86

6 Wu S, Zhang G, Huang Y, et al. Gas hydrate occurrence on the continental slope of the northern South China Sea. Mar Petrol Geol, 2005, 22: 403-412

7 Huang C Y, Chien C W, Zhao M X, et al. Geological study of active cold seeps in the syn-collision accretionary prism kaoping slope off SW Taiwan. Terr Atmos Ocean Sci, 2006, 17: 679-702

8 Liu C S, Schnürle P, Wang Y, et al. Distribution and characters of gas hydrate offshore of Southwestern Taiwan. Terr Atmos Ocean Sci, 2006, 17: 615-644

9 Mcdonnell S L, Max M D, Cherkis N Z, et al. Tectono-sedimentary controls on the likelihood of gas hydrate occurrence near Taiwan. Mar Petrol Geol, 2000, 17: 929-936

10 Zhang Z J, Yu X H, Liu B. Tectonic and sedimentary controls on the likelihood of gas hydrate occurrence near west and south of Taiwan in china (in Chinese). Natur Gas Geosci, 2004, 15: 655-659

11 Wu B H, Zhang G X, Zhu Y H, et al. Progress of gas hydrate investigation in China offshore (in Chinese). Earth Sci Front, 2003, 10: 177-189

12 Zhu Y H, Wu B H, Lu Z Q. The prospecting for gas hydrate offshore china (in Chinese). Miner Deposit, 2001, 20: 174-180

13 Sun C Y, Niu B H, Wang H Y, et al. A study of gas hydrate geochemical exploration and deposit formation patterns in the Xisha ocean (in Chinese). Earth Sci Front, 2005, 12: 243-251

14 Zhang $\mathrm{H}$, Yang S, Wu N, et al. Successful and surprising results for China's first gas hydrate drilling expedition. In: Fire in the Ice Newsletter, Fall, 2007. 6-9
15 Huang Y Y, Suess E, Wu N Y. The geological background and identifies of gas hydrate in Dongsha area (in Chinese). In: Symposium of Gas Hydrate on Both Sides of the Taiwan Strait, 2005. 3-4

16 Wang S, Yan W, Song H. Mapping the thickness of the gas hydrate stability zone in the South China Sea. Terr Atmos Ocean Sci, 2006, 17: $815-828$

17 Zhang M, Sun X M, Lu Y, et al. Mineralogy of authigenic tube pyrites from the offshore areas of Southwest Taiwan, South China Sea, and its indicating significance to gas hydrate. Mineral Deposits, 2011, 30: 3

18 Guo T M, Wu B H, Zhu Y H, et al. A review on the gas hydrate research in China (in Chinese ). J Petrol Sci Eng, 2004, 41:11-20

19 Feng Y L, Yu L J. The structure characteristics of Nanometer graphite cone occurred in sujiquan graphite deposit (in Chinese). Bull Chin Ceramic Soc, 2007, 26: 9-12

20 Lin S, Huang K M, Chen S K. Organic carbon deposition and its control on iron sulfide formation of the southern East China Sea continental shelf sediments. Cont Shelf Res, 2000, 20: 619-635

21 Luque F J, Ortega L, Barrenechea J F, et al. Deposition of highly crystalline graphite from moderate-temperature fluids. Geology, 2009, 37: 275-278

22 Luque F J, Pasteris J D, Wopenka B, et al. Natural fluid-deposited graphite: mineralogical characteristics and mechanisms of formation. Am J Sci, 1998, 298: 471-498

23 Luque F J, Rodas M. Constraints on graphite crystallinity in some Spanish fluid deposited occurrences from different geologic settings. Miner Deposit, 1999, 34: 215-219

24 Pasteris J D, Chou I M. Fluid-deposited graphitic inclusions in quartz: Comparison between KTB (German continental deep-drilling) core samples and artificially re-equilibrated natural inclusions. Geochim Cosmochim Acta, 1998, 62: 109-122

25 Pasteris J D. Causes of the uniformly high crystallinity of graphite in large epigenetic deposits. J Metamorph Geol, 1999, 17: 779-787

26 Kvenvolden K A. Methane hydrate-A major reservoir of carbon in the shallow geosphere. Chem Geol, 1988, 71: 41-51

27 Lee C J, Park J, Yu J. Catalyst effect on carbon nanotubes synthesized by thermal chemical vapor deposition. Chem Phys Lett, 2002, 360: 250-255

28 Libera J, Gogotsi Y. Hydrothermal synthesis of graphite tubes using Ni catalyst. Carbon, 2001, 39: 1307-1318

29 Hata K, Futaba D N, Mizuno K, et al. Water-assisted highly efficient synthesis of impurity-free single-waited carbon nanotubes. Science, 2004, 306:1362-1364

Open Access This article is distributed under the terms of the Creative Commons Attribution License which permits any use, distribution, and reproduction in any medium, provided the original author(s) and source are credited. 